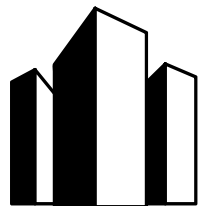

УДК 351.88; 621.039.59
Аспекти публічного управління

Aspekty publichnoho upravlinnya

Public administration aspects

Public administration aspects. 2016. 37-38(11-12), 32-39. doi:10.15421/15201659

www.aspects.org.ua

\title{
Ukraine International cooperation in nuclear and radiation safety: public-administrative aspect
}

\section{I.P. Krynychnay ${ }^{1}$, I.I. Hozhiloº ${ }^{2}$ O.I. Djachenko ${ }^{3}$}

The article examines international cooperation of Ukraine with other States in the sphere of ensuring nuclear and radiation safety and highlights the main directions of development and improvement of nuclear and radiation safety in Ukraine based on international experience, with the aim of preventing the risks of accidents and contamination areas radiological substances. Illuminated that for more than half a century of experience in the use of nuclear energy by the international community under the auspices of the UN, IAEA and other international organizations initiated and monitored the implementation of key national and international programs on nuclear and radiation safety. Of the Convention in the field of nuclear safety and the related independent peer review, effective national regulatory infrastructures, current nuclear safety standards and policy documents, as well as mechanisms of evaluation in the framework of the IAEA constitute important prerequisites for the creation of a world community, the global regime of nuclear and radiation safety. For analysis of the state of international cooperation of Ukraine with other States in the sphere of nuclear and radiation safety, highlighted the legal substance of nuclear and radiation safety of Ukraine, which is enshrined in the domestic Law of Ukraine "On nuclear energy use and radiation safety». Considered the most relevant legal relations. It is established that, despite the current complex international instruments, existing domestic legislation on nuclear and radiation safety, partly there is a threat of emergency nuclear radiation nature, in connection with the failure of fixed rules and programs, lack of funding from the state is not always on time and in full allows you to perform fixed strategy for overcoming the consequences of radiation accidents, the prevention of the threat of environmental pollution. Found that to improve and further ensuring nuclear

${ }^{I}$ Doctor of public administration, Full Prof.; Dnepropetrovsk regional institute of public administration, the National academy of public administration under the President of Ukraine, 29, Gogol Str., Dnipro, 49044, Ukraine ${ }^{2}$ Doctor of public administration, Full Prof.; Dnepropetrovsk regional institute of public administration, the National academy of public administration under the President of Ukraine, 29, Gogol Str., Dnipro, 49044, Ukraine

${ }^{3}$ Postgraduate; Dnepropetrovsk regional institute of public administration, the National academy of public administration under the President of Ukraine, 29, Gogol Str., Dnipro, 49044, Ukraine

${ }^{4}$ Доктор наук з державного управління, професор; Дніпропетровський регіональний інститут державного управління Національної академії державного управління при Президентові України, 49044, Дніпро, вул. Гоголя, 29

${ }^{5}$ Доктор наук з державного управління, професор; Дніпропетровський регіональний інститут держсавного управління Національної академії державного управління при Президентові України, 49044, Дніпро, вул. Гоголя, 29

${ }^{6}$ Аспірант; Дніпропетровський регіональний інститут державного управління Національної академії держсавного управління при Президентові України, 49044, Дніпро, вул. Гоголя, 29

${ }^{7}$ Доктор наук государственного управления, профессор; Днепропетровский региональный институт государственного управления Национальной академии государственного управления при Президенте Украины, 49044, Днепр, ул. Гоголя, 29

8 Доктор наук государственного управления, профессор; Днепропетровский региональный институт государственного управления Национальной академии государственного управления при Президенте Украины, 49044, Днепр, ул. Гоголя, 29

9 Аспирант; Днепропетровский региональный институт государственного управления Национальной академии государственного управления при Президенте Украины, 49044, Днепр, ул. Гоголя, 29

E-mail: barkry@bk.ru 
and radiation safety of Ukraine, it is necessary to implement a clear state regulation in the sphere of execution implementation international norms and standards, implementation of the ratified documents and the existing domestic legal framework, constantly monitoring, coordination and control in relation to the goals and objectives. The study performed on the basis of international regulations, legislation of Ukraine and published documents.

Keywords: public administration; international cooperation; nuclear safety; radiation safety; international programs

\section{Міжнародне співробітництво України у сфері ядерної та радіаційної безпеки: державно-управлінський аспект}

\section{I.П. Кринична ${ }^{4}$, I.I. Хожило ${ }^{5}$, О.І. Дяченко ${ }^{6}$}

У статті аналізується міжнародне співробітництво України з іншими державами у сфері гарантування ядерної та радіаційної безпеки та виділяються основні вектори розвитку і вдосконалення ядерної та радіаційної безпеки в Україні з урахуванням міжнародного досвіду, з метою попередження ризиків аварій та забруднення території радіаційними речовинами. Розглянуті найбільш актуальні договірно-правові відносини. 3'ясовано, що для покращення та подальшого забезпечення ядерної та радіаційної безпеки України, необхідно здійснювати чітке державне регулювання у сфері виконання імплементованих міжнародних норм та встановлених стандартів, виконання ратифікованих документів та діючу вітчизняну законодавчу базу, постійно здійснювати моніторинги, координацію та контроль щодо поставлених цілей та завдань. Дослідження виконано на основі міжнародних нормативних документів, законодавчої бази України та опублікованих документів.

Ключові слова: державне управління; міжнародне співробітництво; ядерна безпека; радіаційна безпека; міжнародні програми

\section{Международное сотрудничество Украины в сфере ядерной и радиационной безопасности: государственно-управленческий аспект}

\section{И.П. Криничная ${ }^{7}$ И.И. Хожило ${ }^{8}$, А.И. Дяченко 9}

В статье анализируется международное сотрудничество Украины с другими государствами в сфере обеспечения ядерной и радиационной безопасности, при этом выделяются основные векторы развития и совершенствования ядерной и радиационной безопасности в Украине с учетом международного опыта, с целью предупреждения рисков аварий и загрязнения территории радиационными веществами. Рассмотрены наиболее актуальные договорно-правовые отношения. Выяснено, что для улучшения и дальнейшего обеспечения ядерной и радиационной безопасности Украины необходимо осуществлять четкое государственное регулирование в сфере выполнения имплементированных международных норм и установленных стандартов, выполнения ратифицированных документов и действующей отечественной законодательной базы. Постоянно осуществлять мониторинги, координацию и контроль в отношении поставленных целей и задач. Исследование выполнено на основе международных нормативных документов, законодательной базы Украины и опубликованных документов.

Ключевые слова: государственное управление; международное сотрудничество; ядерная безопасность; радиационная безопасность; международные программы

Peer-reviewed, approved and placed: 11.10.2016.

Problem statement. Safe use of the nuclear power today is attributable to the strict compliance with international agreements relating to almost every aspect of nuclear and radiation safety.

Internationally agreed and regularly revised standards, recommendations and guidelines cover now almost all stages of nuclear opera- tions, from ore extraction and production of nuclear fuel to the disposal of nuclear waste. Despite positive development trends in the sphere of international nuclear safety in the last decade of the XX century, real objective and subjective conditions, that affect negatively the future of nuclear energy, appeared due to socio-political and economic changes in society, the systemic 
crisis and misunderstanding between the countries. This caused the emergence of new challenges and threats which pose real hazards to international peace and stability. [15]

Recent researches and publications' analysis. To write this article, an analysis of the international law in the sphere of nuclear and radiation safety has been made, the legal Ukrainian framework and bilateral international legal instruments of Ukraine and other countries have been studied. Published work of such scientists as M. Zemlyaniy, V. Velychkin, A. Shevtsov, N. Kiseljeva, I. Krynychna, O.Yatsenko, B. Danylyshyn and others have been processed while writing the article. Despite significant scientific achievements of domestic scientists in this sphere, the issue of Ukraine's international cooperation in the sphere of nuclear and radiation safety in the context of public administration has not been highlighted enough and that has led the choice of the research topic.

The purpose of the study is to improve the public administration in the sphere of nuclear and radiation safety of Ukraine by strengthening of the international cooperation.

Research methods. Theoretical and methodological basis of the article is a set of scientific methods and approaches arising from the specific object and purpose of the study.

Presentation of the main material. Characteristic feature of the modern stage of Ukraine's socio-economic development is the further development of nuclear energy. Consequences of this process are not limited by fields of science, technology, medicine, and are reflected in various life spheres, including nuclear power. However, it is well known that the nuclear energy use is associated with a significant life and activity's risk both for individual people and whole nations, and even for the existence of the Earth. Nuclear radiation is the exclusive source of the increased danger, which in its power exceeds all known before sources of danger. That's why its production and use requires adequate reflection in the legal sphere of society and requires appropriate legal regulations. [14

International cooperation is carried out in accordance with the priority areas, which ensure Ukraine's entry into the international legal environmental space, the implementation of modern system of standards and norms, which is harmonized with international scientific and technological policy, obtaining technical assis- tance in the sphere of environmental protection, nuclear and radiation safety and rational use of natural resources, the solution of problems related to the closure of Chernobyl atomic electrical station (CAES), the introduction of economic instruments of environmental management, staff training, getting of information, databases and software products in the sphere of environmental protection. Ukraine participates in the work of leading intergovernmental organizations which activities are aimed at solving of environmental protection and nuclear safety's problems.

The objective necessity of international cooperation in the sphere of environmental protection at the international level stems from the nature of the global environmental crisis. Nowadays, the process of formation of new social, economic and ethical system of values, including environmental imperative, has started. Present time is marked by the understanding of counties' mutual responsibility for state of the environment. It has become a norm of international cooperation in the sphere of environmental problems' solving, mutual consultations and exchange of information has become a norm of international communication. The main aim of this is to develop the system of global environmental security. [7]

Ukraine has implemented a significant number of national and international technical cooperation programs. Ukraine is a recipient of international technical assistance programs of the European Commission. In particular, the State Enterprise «State Scientific and Technical Center for Nuclear and Radiation Safety» (hereinafter - SSTC) participates in the European Commission's TACIS, INSC and IfS programs. According to the International USA Nuclear Safety Program more than 80 projects were opened during 1992-2011 years. Ukraine also gets financial assistance from the European Bank for Reconstruction and Development, World Bank, IMF and other international organizations.

The main donor countries of bilateral aid are the USA, Germany, France, Finland, Sweden. Technical assistance is aimed mainly at the raise of the technological level of the international technical assistance's recipient (hereinafter - ITA) and is provided in the form of no cost technology grant or projects, which fund the technological development in cooperation with countries-recipients on a bilateral or multilateral basis, including assistance through international 
organizations (consultations of foreign experts, financing of expenses for the independent researches conducting, staff training and retraining, informing of new technologies, funding of equipment's' supplies and grants). Principles of priority, complementarity of projects and the absence of themes' overlapping are implemented while using the international technical assistance. In Ukraine the main recipient of the ITA in the nuclear and radiation safety sphere is the State Nuclear Regulatory Committee of Ukraine. International scientific-technical cooperation SSTC is an integral part of the international activity of the Nuclear Regulatory Committee, within which a purposeful systematic work is conducted. This work is aimed at getting and developing modern methodologies, carrying out joint projects and sharing of experiences with foreign experts in areas related to the regulation and safety assessment of Ukrainian civilian nuclear facilities [6].

The Nuclear Regulatory Committee of Ukraine and the State Enterprise «State Scientific and Technical Center for Nuclear and Radiation Safety», which are organizations of scientific and technical support to the regulator, carry out active international activity, which is aimed at performing of urgent tasks in the sphere of nuclear and radiation safety in Ukraine according to the international standards and international experience. Bilateral cooperation of SSTC NRS is focused mainly on interactions with regulatory authorities and other states' technical support organizations. Multilateral cooperation occurs within the framework of international organizations, associations, programs and projects. Participation in the international technical assistance programs and fulfilment of contracts for the provision of technical services are important components of the international activity of SSTC NRS. Thus, cooperation under the programs of the European Commission such as the Instrument of the Nuclear Safety Cooperation (INSC) and the Instrument for Stability (IfS) provides an effective combination of international and domestic experience in the sphere of the nuclear radiation safety's assessment. Works are carried out under the projects of the technical assistance to Ukraine and other countries. SSTC NRS is actively trying to expand the geography of its international activities by participating in international tenders, which are held by the European Commission. Subjects of these projects include scientific and technical support to the licensing of life cycle stages of existing Ukrainian nuclear power plants, design and construction of facilities for the decommissioning of nuclear power plants, independent radiation monitoring of areas where radiative and nuclear technologies are used, and sharing the experience of the use of modern methods of expert safety assessment. A special place in the international cooperation of SSTC NRS is given to the enforcement of grant agreements with the European Bank for Reconstruction and Development for the implementation of projects, which are financed by international funds: Chernobyl Shelter fund supports the project «License consultant» and «Nuclear safety» fund takes care about a project, which supports activity of the State Nuclear Regulatory Committee of Ukraine concerning licensing of Repository for Spent Nuclear Fuel (RSNF-2) and the Plant for Processing Liquid Radioactive Waste (PPLRW) [3].

According to the Agreement between Ukraine and the United States of America as to peaceful use of the nuclear energy, the Government of Ukraine and the Government of the United States reaffirm their commitments ensuring that the international development and use of the nuclear energy for peaceful purposes are carried out under conditions that facilitate the aim of The Agreement on the nuclear weapons Proliferation (hereinafter - ANWP) as much as possible; assure their support for the goals of the International Atomic Energy Agency (IAEA); reaffirm their commitments to strengthen IAEA guarantees, including a readiness to take steps, which are necessary to enable the Agency to apply guarantees effectively and efficiently and to achieve the purposes of its inspection tasks in institutions, which belong to the jurisdiction of the Parties; confirmation of their decision to act in accordance with the principles, written in the guide for Movement of Nuclear Material of $\mathrm{Nu}$ clear Suppliers Group; focusing the importance of the principles of the Nuclear Suppliers Group on full-scope IAEA guarantees such as the conditions of movement to countries that do not possess nuclear weapons; on the control of dual use items; the introduction of export restrictions of non-publicly accessible items; confirmation of the importance of the effective control of nuclear materials' support, as well as accounting and physical protection in accordance with international standards; seek cooperation in the development, use and control of tools of nuclear en- 
ergy's peaceful use. Parties cooperate in the field of the use of nuclear energy for peaceful purposes in accordance with the provisions of this Treaty and the related agreements, state laws, regulatory structures, licensing requirements [13].

Cooperation with the USA Nuclear Regulatory Commission (NRC) is based on a Memorandums of Cooperation between regulatory bodies of both countries, which is adopted by the parties annually, and is carried out within projects with Brookhaven National Laboratory (BNL) on directions: regulatory review and oversight activities, risk-based regulatory activity, fragility of reactors' pressure vessels, emergency response and related capabilities, project management, accounting and control of nuclear materials and physical protection, legal framework [3].

According to the Memorandum on cooperation and mutual assistance on nuclear and radiation security between the governments of states - members of the Organization for Democracy and Economic Development - GUAM, the Government of the Republic of Azerbaijan, the Government of Georgia, the Government of the Republic of Moldova, the Cabinet of Ministers of Ukraine.

expressing the desire to further strengthening and development of fruitful cooperation and mutual assistance in the sphere of nuclear and radiation safety, understanding the importance of joint efforts and dissemination of the positive experience of the implementation of modern approaches and regulatory principles in the spheres of nuclear and radiation safety on the basis of international standards, which take into account the development of science and technologies; guided by international standards and requirements for radiation protection of population and environment, safety of handling of radioactive wastes, radioactive sources of ionizing radiation, including the issues of their physical protection; reiterating the compliance to the Code of Conduct on the security and radioactive sources' safety; taking into consideration the fact that GUAM member states are members of the International Atomic Energy Agency (IAEA) and they develop cooperation on regulation nuclear and radiation safety in order to:

create and improve the legislation and national infrastructures in the sphere of nuclear and radiation safety; develop coordinated ways to respond in case of man-made disasters' emer- gency situations; improve the safety and protect against modern threats, including terrorism and illegal movement of nuclear and radioactive materials. The main areas of cooperation are: exchange of information on legislative support of governing the nuclear and radiation safety; sharing the experience on practical response to nuclear or radiological emergencies, including those, which are based on procedures and methods, set out in IAEA technical documents; sharing the experience on handling of sources of ionizing radiation, including maintenance of its conservation and also handling of radioactive waste and nuclear materials, including procedures for licensing, registration and monitoring their movements; cooperation in the process of the implementation of IAEA's regional projects; timely mutual informing about any incidents, which can influence the nuclear and radiation security in the territories of GUAM member states, taking into account the possible cross-border transfer of radioactive substances in cases of unforeseen emissions, and other mutually interesting areas of cooperation [5].

Working meeting «Interaction of nuclear regulation's authorities with the members of public and the media» was held in Kiev on November 21, 2016. It was organized by the German Association on installations and reactors' security (GRS). Among the participants were experts from nuclear regulators from Ukraine, Germany, Bulgaria, Belarus, Georgia, Turkey, Kazakhstan, Kyrgyzstan, Lithuania and other countries. The issue of the participation of states in the formation and development of nuclear and radiation safety of Ukraine was discussed at the meeting, plans concerning the continuation of the fruitful cooperation between the NRCU and GRS in order to strengthen the system of nuclear regulation in Ukraine were suggested[1].

Nuclear Regulatory Committee of Ukraine and the Institute of Radiation Protection and $\mathrm{Nu}-$ clear Safety, France (hereinafter - IRSN) have a long history of cooperation in the sphere of nuclear and radiation safety. These organizations started their cooperation in 1990 in the format of the European Union TACIS program (in the sphere of nuclear safety), which in 2007 was transformed into INSC (Instrument of Nuclear Safety Cooperation) in order to improve the level of nuclear safety of nuclear installations, including Ukraine. Cooperation includes a wide range of technical issues such as safety 
assessment of nuclear installations, radiation safety (man and environment), modernization of existing nuclear power plants, radioactive waste management and decommissioning of nuclear facilities. Participation of the Technical Assistance Organisation of NRCU in this activity in cooperation with the IRSN is also expanding. In 2010 NRCU was integrated into the network of European Security Organizations ETSON. ETSON has encouraged IRSN to intensify the participation in the European network of nuclear safety. This will bring together Technical Assistance Organisations of nuclear countries in Europe - NRCU in Ukraine and IRSN in France. The Fukushima-Daichi accident revealed the extraordinary necessity to collaborate and to improve constantly the level of nuclear safety worldwide. Ukraine has unique experience for international partners in crisis management after the Chernobyl disaster. That was the basis for last relationships between NRCU and IRSN, and today they have received the impetus to deeper cooperation [2].

According to the Agreement between the State Nuclear Regulatory Inspectorate of Ukraine and the Norwegian Radiation Protection Agency on cooperation in the sphere of nuclear and radiation safety, Ukraine wants to establish close and long-term cooperation in the sphere of safety regulation of the use of nuclear energy, radioactive materials and radiation sources in order to minimize the hazards of radiation onto the human health and the environment while using radioactive materials, cooperation under this Agreement is aimed at regulative activity of SNRIU and NRPA in the sphere of nuclear safety and security. Areas of interest for cooperation include, but are not limited by the following areas: security of nuclear facilities; radioactive wastes management, including the disposal; safety and security of radiation sources; emergency readiness and response; rehabilitation of abandoned sites, including uranium and uranium processing enterprises; radiation protection; transportation of radioactive materials; handling of radioactive materials, which contain naturally occurring radionuclides; medical radiation; physical protection [9].

Within the framework of cooperation between Ukraine and Sweden, a number of bilateral agreements have been signed, such as the Agreement between the State Nuclear Regulatory Committee of Ukraine and the Swedish Au- thority on Radiation Safety on cooperation in nuclear safety and radiation protection, according to which the cooperation between the parties is carried out in the following areas: regulation of nuclear safety, security of nuclear installations, nuclear materials and other sources of ionizing radiation and radiation protection, including handling of radioactive waste and worked-out nuclear fuel, safety of radiation sources, the transportation of radioactive materials and mining of uranium ore, non-proliferation of nuclear weapons, including accounting and control of nuclear materials, transportation safety, physical protection, and combating illegal trafficking of nuclear and other radioactive materials and radiation sources; regulatory procedures and methods of the safety assessment and licensing of the activity at stages of nuclear facilities' life cycle; radiation safety and the regulation of radiation protection in the field of use of ionizing radiation in medicine, industry and researches, as well as handling of radioactive waste, which is left after the use of such sources; emergency readiness and crisis response; other issues of mutual interest of the Parties [8].

The next document is the Agreement on cooperation between Ukrainian State Committee on Nuclear and Radiation Safety (USCNRS) and the Swedish Nuclear Power Inspectorate (SKI) on activity, related to the non-proliferation of nuclear weapons, which establishes bilateral cooperation between regulatory authorities of Ukraine and Sweden in order to help Ukraine and to assist it in the creation of System of Security Measures based on the Swedish and international experience, including the free provision of necessary technical and administrative equipment and resources associated with such activities. [12]

According to the Agreement between the Cabinet of Ministers of Ukraine and the Government of Sweden on Early Notification of a Nuclear Accident and the exchange of information on nuclear facilities, the cooperation is aimed at the minimization of impacts of cross-border transferring of radioactive materials and is important for both countries. [10]

Next Agreement between the Cabinet of Ministers of Ukraine and the Government of Sweden on cooperation in nuclear safety, aims to promote the cooperation in the sphere of nuclear safety, radiation protection, system of guarantees, including the accounting of materials, phys- 
ical protection, control over export and import and illicit trafficking of nuclear materials and equipment during peaceful use of nuclear energy. [11]

In 2010-2013 SNRCU signed a number of agreements on scientific and technical cooperation: an agreement on joint scientific and technical activities with JSC «STC NRS», State Committee under the Government of the Republic of Armenia; the State Scientific Institution «Joint Institute for Energy and Nuclear Research Sosny» of the National Academy of Sciences of Belarus; Institute for Nuclear Research «Rzhezh» of Czech Republic, the Italian company «Independent technical assessment and analysis» (ITER-Consult); Federal State Enterprise «STC NRS» of Russia; Lithuanian Energy Institute (LEI). In the framework of international projects SNRCU experts have received practical skills of the use of more than 30 advanced computer calculating codes and have adapted them for calcu- lations according to technical specifications and features of nuclear plants in Ukraine; the modern methodological basis of safety assessments in accordance with the standards and recommendations of the IAEA has been created [3].

Conclusions and suggestions. Thus, having analysed Ukrainian international cooperation in nuclear and radiation safety of Ukraine and modern national legal framework, it is necessary to emphasize Ukraine's commitment to maintain the nuclear and radiation safety in the country at the international level, as this issue is interstate. Therefore, it should be noted that in order to improve and to insure further nuclear and radiation safety of Ukraine, it is necessary to provide clear state regulation of the fulfilment of implemented international norms and established standards, to implement ratified documents and existing national legislative framework, to monitor constantly, to coordinate and to control the set goals and objectives.

\section{БІБЛІОГРАФІЧНІ ПОСИЛАННЯ:}

1. Державна інспекція ядерного регулювання України. GRS проводить робочу зустріч у Києві від 21 листопада 2016 р. [Електронний ресурс] - Режим доступу: http://www.snrc.gov.ua/nuclear/uk/publish/article/342343.

2. Державна інспекція ядерного регулювання України. Держатомрегулювання України та IRSN Франції посилили співробітництво від 29 квітня 2015p. [Електронний ресурс] - Режим доступу : http://www.snrc.gov.ua/nuclear/uk/publish/article/279829; jsessionid=FFF4775AEE14C208E9A69F6B19EAE304.app1.

3. Державне підприємство «Державний науково-технічний центр з ядерної та радіаційної безпеки» ДНТЦ ЯРБ. Міжнародне співробітництво [Електронний ресурс] - [Режим доступу]: http://sstc.kiev.ua/diialnist/mizhnarodne-spivrobitnytstvo.

4. Закон України «Про використання ядерної енергії та радіаційну безпеку України» [Електронний ресурс]: № 39/95-ВР від 08.02.1995p.- - Режим доступу : http://zakon2.rada.gov.ua/laws/show/39/95-вр.

5. Меморандум о сотрудничестве и взаимопомощи по вопросам ядерной и радиационной безопасности между Правительствами государств - членов Организации за демократию и экономическое развитие - ГУАМ [Електронний ресурс]: № 886_007 Міжнародний документ від 19.06.2007, затвердження від 05.12.2007p. - Режим доступу: http://zakon3.rada.gov.ua/ laws/show/886 007.

6. Механізм імплементації програм міжнародної технічної допомоги в аспекті керування проектним циклом [Електронний ресурс]: / Ю. В. Ссипенко, Л. К. Єрмакова, Т. А. Мурзіна, О. В. Петренко, О. М. Яценко // ISSN 2073-6231. Ядерна та радіаційна безпека. - 2013.- № 1(57) - [Режим доступу]:. http://www.nbuv.gov.ua/old jrn/natural/Yarb/2013 1/1_13 12.pdf

7. Міжнародне співробітництво України з вирішення екологічних проблем сучасності [Електронний ресурс]: / Н. П. Бунда, I. Л. Цимбалюк // Сучасні інтеграційні процеси і міжнародне співробітництво. - 2008. - № 6 - [Режим доступy]:http://www. nbuv.gov.ua/old_jrn/natural/nvvnu/misnarod_vidnos/2008_6/R4/4.pdf

8. Угода між Державним комітетом ядерного регулювання України та Шведським органом з радіаційної безпеки про співробітництво в галузі ядерної безпеки та радіаційного захисту [Електронний ресурс]: № 752_053, Міжнародний документ від 14.01.2010, підписання від 14.01.2010p. - Режим доступу: http://zakon2.rada.gov.ua/laws/show/752_053.

9. Угода між Державною інспекцією ядерного регулювання України та Норвезьким агентством радіаційного захисту про співробітництво в сфері ядерної та радіаційної безпеки [Електронний ресурс]: № 578 025, Міжнародний документ від 18.11.2014, підписання від 18.11.2014p. - Режим доступу: http://zakon2.rada.gov.ua/laws/show/578 025.

10. Угода між Кабінетом Міністрів України та Урядом Королівства Швеція про оперативне сповіщення про ядерні аварії та обмін інформацією про ядерні установки [Електронний ресурс]: № 752_006, Міжнародний документ від 23.03.1999p., прийняття від 23.03.1999p. - Режим доступу: http://zakon4.rada.gov.ua/laws/show/752_006.

11. Угода між Кабінетом Міністрів України та Урядом Королівства Швеція про співробітництво в галузі ядерної безпеки [Електронний ресурс]: №752 005, Міжнародний документ від 23.03.1999p., ратифікація від 23.03.2000р. - Режим доступу: http://zakon2.rada.gov.ua/laws/show/en/752_005.

12. Угода про співробітництво між державним комітетом України з питань ядерної і радіаційної безпеки (Укрдержкомядербезпеки) та Шведським інспекторатом ядерної енергетики (SKI) щодо діяльності, пов'язаної з нерозповсюдженням ядерної зброї [Електронний ресурс]: № 752 019, Міжнародний документ від 17.08.1993р., підписання від 17.08.1993 р. - Режим доступу: http://zakon2.rada.gov.ua/laws/show/752_019.

13. Угода про співробітництво між Україною та Сполученими Штатами Америки стосовно мирного використання ядерної енергії [Електронний ресурс]: № 840 020 Міжнародний документ від 06.05.1998, ратифікація від 19.03.1999 р. - Режим доступу: http://zakon4.rada.gov.ua/laws/show/840_020. 
14. Ядерна та радіаційна (радіоекологічна) безпека в системі екологічної безпеки [Електронний ресурс] - [Режим доступу]: http://www.referat-sochinenie.ru/add/ekologiya_i_ohrana_prirody/yaderna_ta_radacina_radoekologchna_bezpeka_v_sistem_ ekologchno bezpeki.html.

15. Ядерно-радіаційний тероризм - глобальна загроза - [Електронний ресурс] - [Режим доступу]: http://pidruchniki. com/72509/ekologiya/yaderno-radiatsiyniy_terorizm_globalna_zagroza.

\section{REFERENCES:}

1. Derzhavna inspektsiya yadernoho rehulyuvannya Ukrayiny. GRS provodyt' robochu zustrich v Kyyevi vid 21 lystopada 2016 [State Nuclear Regulatory Inspectorate of Ukraine. GRS conducts a meeting in Kiev on 21 November 2016]. Access: http://www. snrc.gov.ua/nuclear/uk/publish/article/342343 (in Ukrainian).

2. Derzhavna inspektsiya yadernoho rehulyuvannya Ukrayiny. Derzhatomrehulyuvannya Ukrayiny ta IRSN Frantsiyi posylyly spivrobitnytstvo vid 29 kvitnya 2015 [State Nuclear Regulatory Inspectorate of Ukraine. IRSN Nuclear Regulatory Committee of Ukraine and France intensified cooperation on April 29, 2015]. Access: http://www.snrc.gov.ua/nuclear/uk/publish/article/279829;jsessionid= FFF4775AEE14C208E9A69F6B19EAE304.app1 (in Ukrainian).

3. Derzhavne pidpryyemstvo «Derzhavnyy naukovo-tekhnichnyy tsentr z yadernoyi ta radiatsiynoyi bezpeky» DNTTs YaRB. Mizhnarodne spivrobitnytstvo [The State Enterprise "State Scientific and Technical Center for Nuclear and Radiation Safety" SSTC. International cooperation]. Access: http://sstc.kiev.ua/diialnist/mizhnarodne-spivrobitnytstvo (in Ukrainian).

4. Zakon Ukrayiny «Pro vykorystannya yadernoyi enerhiyi ta radiatsiynu bezpeku Ukrayiny» № 39/95-VR vid 08.02.1999 [The Law of Ukraine "On Nuclear Energy and Radiation Safety of Ukraine” № 39 / 95- 08.02.1995]. Access: http://zakon2.rada.gov.ua/laws/ show/39/95-vr (in Ukrainian).

5. Memorandum o sotrudnychestve y vzaymopomoshchy po voprosam yadernoy y radyatsyonnoy bezopasnosty mezhdu Pravytel'stvamy hosudarstv - chlenov Orhanyzatsyy za demokratyyu y эkonomycheskoe razvytye - HUAM № 886007 Mizhnarodnyy dokument vid 19.06.2007, zatverdzhennya vid 05.12.2007 [Memorandum on cooperation and vzaymopomoschy question on nuclear and radiation safety Between Government states - Chlenov Organization for democracy and эkonomycheskoe Development - GUAM number 886007 International Document of 19.06.2007, approval of 05.12.2007]. Access: http://zakon3.rada.gov.ua/laws/ show/886 007 (in Ukrainian).

6. Yesypenko, Yu. V., Yermakova, L. K., Murzina, T. A., Petrenko, O. V., Yatsenko, O. M, 2013. Mekhanizm implementatsiyi prohram mizhnarodnoyi tekhnichnoyi dopomohy $\mathrm{v}$ aspekti keruvannya proektnym tsyklom [The mechanism of implementation of international technical assistance programs in terms of project cycle management]. ISSN 2073-6231. Yaderna ta radiatsiyna bezpeka 1(57). Access: http://www.nbuv.gov.ua/old_jrn/natural/Yarb/2013_1/1_13_12.pdf (in Ukrainian).

7. Bunda, N. P., Tsymbalyuk, I. L., 2008. Mizhnarodne spivrobitnytstvo Ukrayiny z vyrishennya ekolohichnykh problem suchasnosti [International cooperation of Ukraine with the solution of environmental problems]. Suchasni intehratsiyni protsesy i mizhnarodne spivrobitnytstvo 6. Access: http://www.nbuv.gov.ua/old_jrn/natural/nvvnu/misnarod_vidnos/2008_6/R4/4.pdf (in Ukrainian).

8. Uhoda mizh Derzhavnym komitetom yadernoho rehulyuvannya Ukrayiny ta Shveds'kym orhanom z radiatsiynoyi bezpeky pro spivrobitnytstvo $\mathrm{v}$ haluzi yadernoyi bezpeky ta radiatsiynoho zakhystu № 752 053, Mizhnarodnyy dokument vid 14.01.2010, pidpysannya vid 14.01.2010 [Agreement between the State Nuclear Regulatory Committee of Ukraine and the Swedish Radiation Safety Authority on cooperation in nuclear safety and radiation protection number 752_053, International Document of 14.01.2010, signed on 14.01.2010]. Access: http://zakon2.rada.gov.ua/laws/show/752 053 (in Ukrainian).

9. Uhoda mizh Derzhavnoyu inspektsiyeyu yadernoho rehulyuvannya Ukrayiny ta Norvez'kym ahent·stvom radiatsiynoho zakhystu pro spivrobitnytstvo v sferi yadernoyi ta radiatsiynoyi bezpeky № 578_025, Mizhnarodnyy dokument vid 18.11.2014, pidpysannya vid 18.11.2014 [Agreement between the State Nuclear Regulatory Inspectorate of Ukraine and the Norwegian Radiation Protection Agency on cooperation in the field of nuclear and radiation security number 578 025, International Document of 11.18.2014]. Access: http://zakon2.rada.gov.ua/laws/show/578_025 (in Ukrainian).

10. Uhoda mizh Kabinetom Ministriv Ukrayiny ta Uryadom Korolivstva Shvetsiya pro operatyvne spovishchennya pro yadern avariyi ta obmin informatsiyeyu pro yaderni ustanovky № 752 006, Mizhnarodnyy dokument vid 23.03.1999r., pryynyattya vid 23.03.1999 [Agreement between the Government of Ukraine and the Government of Sweden on Early Notification of a Nuclear Accident and the exchange of information on nuclear facilities number 752_006, International Document of 23.03.1999, decision of 23.03.1999].Access: http://zakon4.rada.gov.ua/laws/show/752 006 (in Ukrainian).

11. Uhoda mizh Kabinetom Ministriv Ukrayiny ta Uryadom Korolivstva Shvetsiya pro spivrobitnytstvo v haluzi yadernoyi bezpeky № 752_005, Mizhnarodnyy dokument vid 23.03.1999r., ratyfikatsiya vid 23.03.2000 [Agreement between the Government of Ukraine and the Government of Sweden on cooperation in nuclear safety №752_005, International Document of 23.03.1999, the ratification of 23.03.2000]. Access:: http://zakon2.rada.gov.ua/laws/show/en/752 005 (in Ukrainian).

12. Uhoda pro spivrobitnytstvo mizh derzhavnym komitetom Ukrayiny z pytan' yadernoyi i radiatsiynoyi bezpeky (Ukrderzhkomyaderbezpeky) ta Shveds'kym inspektoratom yadernoyi enerhetyky (SKI) shchodo diyal'nosti, pov»yazanoyi z nerozpovsyudzhennyam yadernoyi zbroyi № 752 019, Mizhnarodnyy dokument vid 17.08.1993r., pidpysannya vid 17.08.1993 [Agreement on cooperation between the State Committee of Ukraine on Nuclear and Radiation Safety (Ukrderzhkomyaderbezpeky) and the Swedish Nuclear Power Inspectorate (SKI) on activities related to the proliferation number 752_019, International Document of 17.08.1993, signed on 08/17/1993]. Access: http://zakon2.rada.gov.ua/laws/show/752_019 (in Ukrainian).

13. Uhoda pro spivrobitnytstvo mizh Ukrayinoyu ta Spoluchenymy Shtatamy Ameryky stosovno myrnoho vykorystannya yadernoyi enerhiyi № 840_020 Mizhnarodnyy dokument vid 06.05.1998, ratyfikatsiya vid 19.03.1999 [Agreement on cooperation between Ukraine and the United States of America concerning peaceful uses of nuclear energy number 840_020 International Document of 06.05.1998, the ratification of 19.03.1999]. Access: http://zakon4.rada.gov.ua/laws/show/840 020 (in Ukrainian).

14. Yaderna ta radiatsiyna (radioekolohichna) bezpeka v systemi ekolohichnoyi bezpeky [Nuclear and Radiation (Radioecology) security system of environmental safety]. Access: http://www.referat-sochinenie.ru/add/ekologiya_i_ohrana_prirody/yaderna_ta_radacina radoekologchna bezpeka_v sistem ekologchno bezpeki.html (in Ukrainian).

15. Yaderno-radiatsiynyy teroryzm - hlobal'na zahroza [Nuclear radiation terrorism - a global threat]. Access: http://pidruchniki. com/72509/ekologiya/yaderno-radiatsiyniy_terorizm_globalna_zagroza (in Ukrainian). 